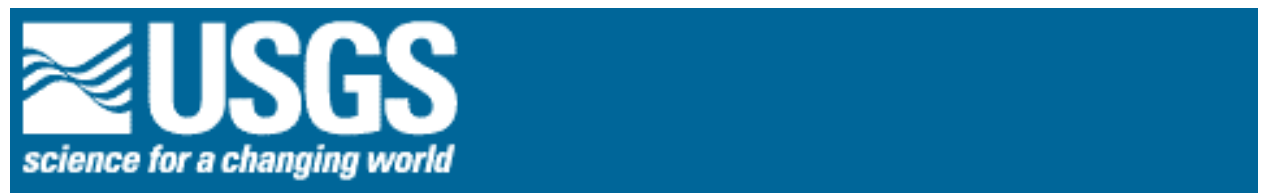

U.S. Geological Survey

Open-File Report 2004-1026

Version 1.0

online only

\title{
Chemistry of Stream Sediments and Surface Waters in New England
}

By Gilpin R. Robinson, Jr., Katherine E. Kapo, and Jeffrey N. Grossman
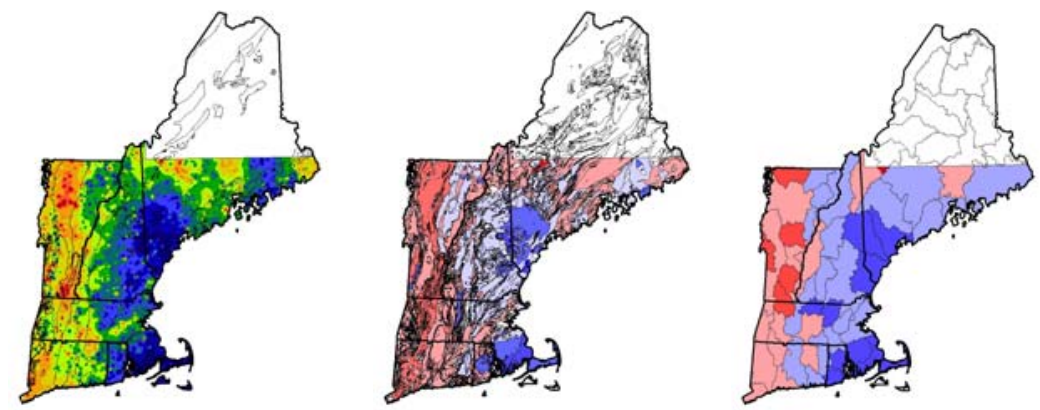

(above: stream sediment chemistry distributions for $\mathrm{Fe}_{2} \mathrm{O}_{3}$ )

\section{Table of Contents:}

1.0 Summary...p.2

2.0 Introduction...p.2

3.0 Source Data...p.3

4.0 Spatial Data Analysis...p.7

5.0 Geochemical Groups and Associations...p.14

6.0 Geochemical Dataset Figure Index...p.16

7.0 References...p.17 


\subsection{Summary}

This online publication portrays regional data for $\mathrm{pH}$, alkalinity, and specific conductance for stream waters and a multi-element geochemical dataset for stream sediments collected in the New England states of Connecticut, Maine, Massachusetts, New Hampshire, Rhode Island, and Vermont. A series of interpolation grid maps portray the chemistry of the stream waters and sediments in relation to bedrock geology, lithology, drainage basins, and urban areas. A series of box plots portray the statistical variation of the chemical data grouped by lithology and other features.

\subsection{Introduction}

The chemistry of sediments and waters at the surface of the earth influence important geochemical and life cycles. The geochemical variability of stream sediments and surface waters result from a complex interaction of a variety of geochemical sources and transport and deposition processes. Important factors for geochemical variability include:

1) Geochemical and mineralogical variation in the source rocks that are the main medium from which soils and sediments develop,

2) Variation in the physiography, erosion, and weathering of the source rocks and the related variation in the deposition and distribution of sediments in drainage basins whose interaction with waters influence water chemistry and sediment mineralogy, and

3) Variation in land use and human-related influences on sediment and water chemistry.

The objective of this work is to concisely describe the geochemical characteristics and portray the spatial distribution and variation of 8 major and 17 minor elements in stream sediments and 3 chemical features of surface waters in relation to geologic units, rock type groups, and population density features whose aerial extent is large enough to be illustrated on a map of New England at a scale of 1:500,000. This portrayal facilitates the comparison of the chemistry in relation to geologic, drainage basin, and other factors and identifies areas of relative enrichment or deficiency due to both geologic and humanrelated phenomena.

\subsection{Background}

From 1977 to 1980, the Hydrogeochemical and Stream Sediment Reconnaissance (HSSR) component of the National Uranium Resource Evaluation (NURE) Program conducted by the Department of Energy collected stream sediments and waters at 8360 sample sites in the New England states of Connecticut, Maine, Massachusetts, New Hampshire, Rhode Island, and Vermont. Field measurements for $\mathrm{pH}$, alkalinity, and conductivity were determined for 7119 sample sites in New England (Figure 1). 7905 stream sediment samples were processed and received at least partial chemical analysis. Information on the NURE samples is given in Smith (2001-a) and the data was released 
in Grossman (1998) and Smith (2001-b). In 1999, a randomly distributed subset of 1597 stream sediment samples were selected for reanalysis by more modern analytical methods from an archive of the NURE stream sediment samples (Figure 2).

\subsection{Source Data}

\subsection{Stream Sediment Chemistry}

The NURE stream sediment samples selected for re-analysis were analyzed for 40 elements by inductively coupled plasma atomic emission spectrometry (ICP-AES) following an acid-dissolution procedure (ICP40), 16 elements by ICP_AES following a lithium metaborate fusion procedure (ICP16), arsenic and selenium by hydridegeneration atomic absorption spectrometry (HGAA) and mercury by cold-vapor atomic absorption (CVAA) (methods described in Taggart, 2002). Uranium and ytterbium values, from the original NURE dataset, were analyzed by instrumental neutron activation analysis (INAA) (Smith, 2001b). Table 1 lists the elements presented in this report and the methods used to determine them. Elements for which detection limits were high relative to typical stream-sediment concentrations are not presented. The stream sediment chemistry database, description of samples, and description of analytical methods is provided by the U.S. Geological Survey (2004).

Table 1. Stream sediment geochemical data presented in this report, categorized by analytical method used:

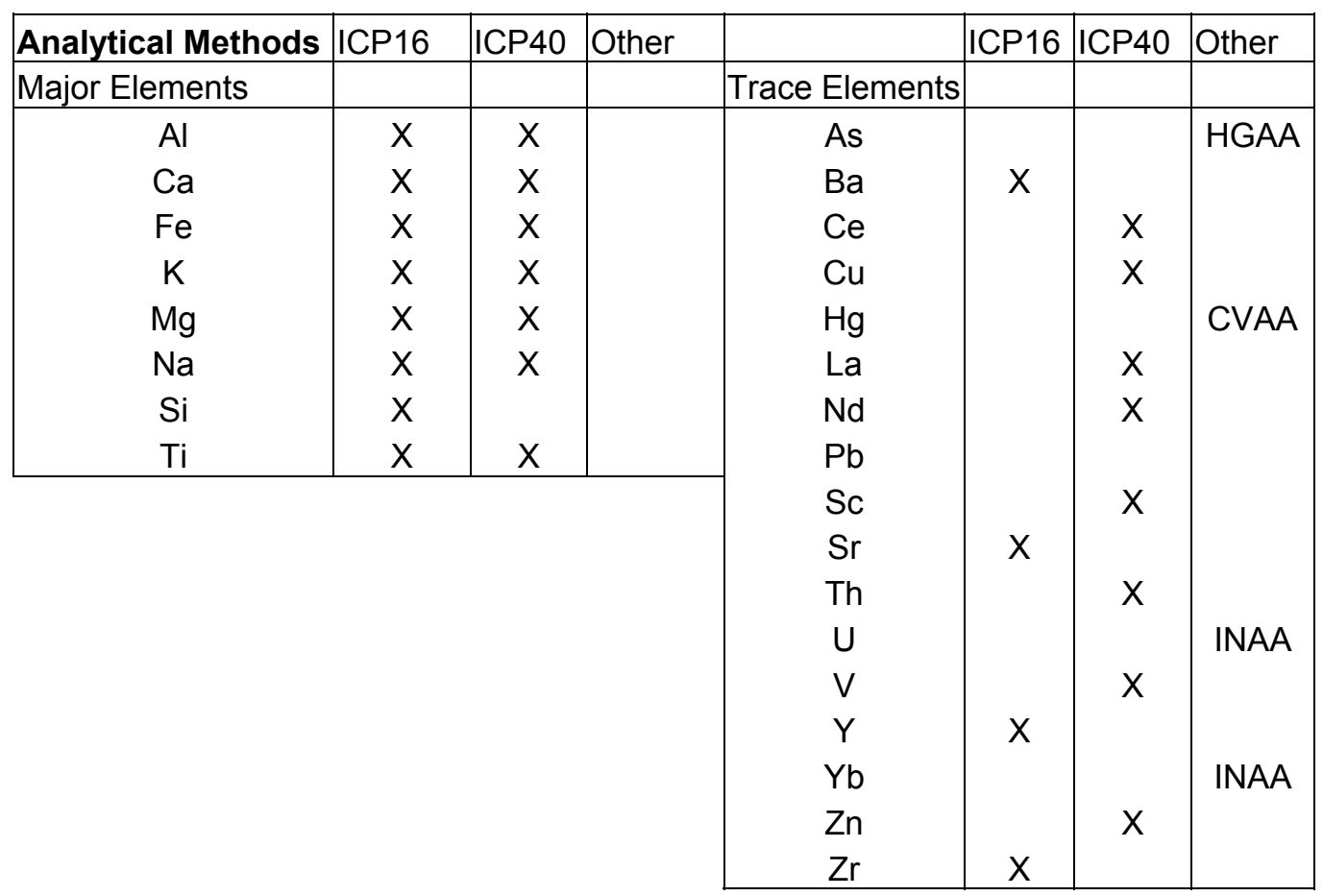




\subsection{Surface Water Chemistry}

Field measurements of stream water $\mathrm{pH}$, alkalinity, and specific conductance determined for steam water at the sediment sample sites during the sampling for the NURE program are reported by the U.S. Geological Survey (2004) and a discussion of analytical methods is given in Smith (2000a). Water $\mathrm{pH}$ was determined by meter. Alkalinity was measured by field titrating drops of $\mathrm{H}_{2} \mathrm{SO}_{4}$ into the water sample until a $\mathrm{pH}$ of approximately 4.5 was reached. The alkalinity is calculated as (drops of $\mathrm{H}_{2} \mathrm{SO}_{4}$ /water volume) expressed as millequivalents of $\mathrm{H}_{2} \mathrm{SO}_{4}$ per liter of sample. Specific conductance was measured at the sample site with a conductivity meter and is reported as micromhos $/ \mathrm{cm}$.

\subsection{Geologic Province}

The bedrock geology of the New England region has been divided into 11 geologic provinces, using geologic province categories modified from Robinson and Kapo (2003). Each province group shares common features of (1) lithology, (2) age of formation, (3) geologic setting, and (4) tectonic history. The province groups generally occur as northeast trending belts that follow the structural fabric of the Appalachian foldbelt and faults in New England. The province boundary lines are provided in the general stream sediment and water chemistry map figures, in order to examine any association with data values and a particular province. Box-plots for stream sediment and water data grouped by province were also created to show these associations. The geologic province groups, listed in general order from west to east, are:

- Grenville Belt: Includes areas of Grenville Basement (PreCambrian Y metamorphic rocks) in western Connecticut, Massachusetts, and Vermont. Principally granitic gneiss and metasedimentary rocks. Includes some Cambrian metasedimentary rocks deposited on Precambrian basement.

- Grenville Shelf Sequence: Principally carbonate rocks and other metasedimentary rocks deposited in a carbonate shelf sequence overlying Grenville basement in western Connecticut, Massachusetts, and Vermont.

- Eugeosynclinal Sequence: Includes slates and pelitic metamorphic rocks in the Taconic Range and schists east of the Grenville Belt. Principally Cambrian to Ordovician pelitic metasedimentary rocks, including metavolcanic layers and lenses of ultramafic rocks.

- Waits River-Gile Mountain Belt: Principally Devonian variably-calcareous metasedimentary rocks in eastern Vermont and the northern Connecticut valley in Massachusetts, intruded by Devonian granite.

- Mesozoic Basin: Triassic to Jurassic age sediments and basalt flows deposited in localized rift basins in central Connecticut and Massachusetts. Intruded by Jurassic diabase and basalt dikes.

- Bronson Hill Belt: Localized along the eastern Connecticut valley from Connecticut to western New Hampshire and northern Maine. Principally Ordovician igneous and metavolcanic rocks overlain by Ordovician to Devonian 
metasedimentary rocks. Sulfidic schists and mafic rocks are common. Intruded by Devonian granites.

- New Hampshire - Maine Sequence: Covers eastern Connecticut, central Massachusetts, eastern New Hampshire, and central Maine. Principally Silurodevonian metasedimentary rocks and Silurodevonian and younger igneous rocks, principally granite.

- Coastal Maine: Localized along northeastern coastal Maine. Principally PreCambrian $Z$ to Silurian metasedimentary and metavolcanic rocks intruded by Devonian granites. Large granite bodies in the Coastal Maine Province are shown separately.

- Avalon Province: Localized in eastern Massachusetts, Rhode Island, and coastal Connecticut. Principally Precambrian $\mathrm{Z}$ granite and granitic gneiss and metasedimentary rocks of Precambrian $Z$ to Ordovician age. Intruded by Ordovician to Devonian granites. Cretaceous sediments and thick areas of Quaternary glacial sediments occur in southern coastal areas.

- Narragansett Basin: Permian conglomerates and other sediments deposited in fault-bounded basins in Avalon province rocks in southeastern Massachusetts and Rhode Island.

- White Mountain Igneous Province: Permian and younger alkalic granites and related volcanics included in the White Mountain Igneous Province category of McHone and Butler (1984).

\subsection{Bedrock Lithology Groups}

The 16 bedrock lithology groups portray the dominant lithology of the map units shown on the bedrock geologic maps covering the states of New England. Geochemical summary maps, grouped by bedrock lithology category, provide a visual display of possible associations between elements or water chemistry characteristics and individual bedrock lithology groups. The Bedrock lithology group categories portrayed on the geochemical summary maps and box plots are derived from the rock group B category in Robinson and Kapo (2003). The Rock Group categories are listed below:

1. Unconsolidated Sediments (areas in the south-coastal part of New England where crystalline bedrock is overlain by Cretaceous marine sediments and thick deposits of glacial sediments)

2. Basin Sediments (2 categories)

a. Mesozoic Basin sediments

b. Narragansett Basin sediments

3. Granitic Rocks (6 categories)

a. Alkali Granites (White Mountain Igneous Province)

b. Peraluminous Granites of late Devonian and younger age

c. Avalon Granites in Avalon Province

d. Grenville Granites in Grenville Province

e. Granites in Coastal Maine Province

f. Other Granites

4. Felsic Volcanics 
5. Mafic Rocks (and their metamorphic equivalents)

6. Metamorphic Rocks (5 categories)

a. Calcareous Protolith:

i. Carbonate rocks

ii. Calcpelites

iii. Calcgranofels

b. Sulfidic Schists

c. Other metamorphic rocks

\subsection{Drainage basin hydrology}

Geochemical summary maps were created showing median stream sediment values (or water chemistry values) by drainage basin area. The drainage basin areas are derived from the Hydrologic Unit Codes (Steeves and Nebert, 1994). These figures provide geochemistry estimates for stream sediments and water chemistry at the local watershed level.

\subsection{Population Density}

The study area was divided into four categories based on population density. The population categories are derived from the U.S. Census Tiger files for population density in the year 2000, with population data grouped by census block (U.S. Census Bureau, 2000). The two urban and two rural categories, and the areas they cover in New England, are defined and listed below (Table 2). Geochemical summary maps and box plots, grouped by population category, are provided for $\mathrm{Cu}, \mathrm{Pb}, \mathrm{Zn}, \mathrm{Hg}$, factor analyses, and water chemistry data. The figures display possible associations between the data and population density, and provide a visual basis for exploring these associations in additional studies.

Table 2. Population density categories on grid maps and box plots:

\begin{tabular}{|c|c|c|} 
Category & Population Density Range & Area of coverage in New England \\
\hline rban - High Density & $>500$ people/sq. mi. & $9 \%$ \\
rban - Low Density & 201-500 people/sq. mi. & $8 \%$ \\
Rural - High Density & 25-200 people/sq. mi. & $41 \%$ \\
Rural - Low Density & 1-25 people/sq. mi. & $42 \%$ \\
\hline
\end{tabular}

(Section 4.0 next page) 


\subsection{Spatial Data Analysis}

\subsection{Grid Interpolation}

The chemical data for stream sediments and waters has been interpolated in grid format to provide a graphical visualization of the regional variation in chemical values. Spatial interpolation is commonly addressed using methods such as kriging, inverse distance weighting, and fitting polynomial, spline, and Fourier series functions to the data to be interpolated. Inverse distance weighting (IDW) and kriging techniques have been recommended in studies comparing interpolation methods (Weber and Englund, 1992, 1994; Englund, Weber, and Leviant, 1992) and both methods are used in this report to compare the results of the different interpolation methods. IDW is a technique that fits the source data accurately and preserves local anomalies in the interpolation grid. Kriging techniques assume the source data have regionalized errors of estimation and generalize the data to minimize estimation variance. Kriging tends to eliminate local anomalies from the interpolation grid to portray a more general trend for the data.

\subsubsection{Grid Map Cell Size, Projection, and legend parameters}

Grid cells for both interpolation methods were determined by the default settings of the respective geostatistical packages used to calculate the grid cell values, and differed by a size of $0.5 \mathrm{~km}^{2}$. Grid cell size for each interpolation grid, produced by the GeoDAS System multifractal IDW interpolation (Cheng 2003), is approximately $1 \mathrm{~km}^{2}$. Grid cell size for the kriging interpolations grids used the default size for the ArcGIS 8 Geostatistical Analyst extension universal kriging interpolation, which is approximately $1.5 \mathrm{~km}^{2}$.

Arcview 3.2 was used to display the final maps, using the Albers Equal-Area Conic map projection with the following parameters: Clarke 1866 geoid, Central Meridian: -71, Reference Latitude: 23, Standard Parallel 1: 29.5, Standard Parallel 2: 45.5, False Easting: 0, False Northing: 0.

The legends for the interpolation grid maps are based on percentiles of the original point data, with the cutoffs between the color-categories being the $20 \mathrm{th}, 30 \mathrm{th}, 40 \mathrm{th}$, $50 \mathrm{th}, 60 \mathrm{th}, 70_{\mathrm{th}}, 80_{\mathrm{th}}, 90_{\mathrm{th}}$, and $95_{\mathrm{th}}$ percentile values. below:

The geochemical units portrayed in the interpolation grid maps are described

Stream Sediments:

- Major elements (8)); values expressed as oxide weight percent.

- Trace elements (16); values in $\mathrm{mg}$ element $/ \mathrm{kg}$ sample, which is equivalent to parts-per-million (ppm).

- Trace-element ratios (1);. Unitless ratio. Stream Waters:

- $\quad p H$, values expressed as $-\log _{10}$ of hydrogen ion activity.

- Alkalinity, and Specific Conductance; units defined in Section 3.2. 


\subsubsection{Multifractal IDW interpolation}

Multifractal inverse distance weighting (IDW) data interpolation was used to generate one set of interpolation grid maps, using the GeoDAS System (phase III) software (Cheng, 2003). IDW interpolation assigns weights to neighboring known values based on distance to the prediction grid cell. The neighbors used in the interpolation of a specific cell value were determined by the default window size setting for the procedure in GeoDAS.

The general IDW spatial model is as follows:

$$
\hat{\mathrm{Z}}\left(s_{0}\right)=\sum_{j=1}^{N} \lambda_{j} \mathrm{Z}\left(s_{j}\right)
$$

where $\hat{Z}$ is the interpolated chemical value, $s_{0}$ is the prediction grid cell $(x, y$ coordinates), $\mathrm{Z}$ is the known chemical value at the spatial location $s \mathrm{j}$, and $\lambda_{\mathrm{j}}$ is the weight given to the known measurement based on distance from $s_{\mathrm{j}}$ to $s_{0}$ (Johnston, et. al 2001).

Multifractal IDW interpolation estimates the distribution of chemical values based on fitted powerlaw trends between chemical value and grid area using the observed data points. For a detailed discussion on multifractal IDW data interpolation, see Cheng (2003, Appendix C) and Agterberg (2001). Unlike kriging and some other methods, multifractal IDW preserves the local variability of the observed points by assigning greater weights to known outlier values (as opposed to smoothing them). Multifractal IDW is a useful data interpolation method for representing geochemical data, which is highly variable and often contains anomalies (Cheng, 2003).

The multifractal IDW interpolation maps for stream sediment and water chemistry are provided in Section 6.0.

\subsubsection{Uncertainty in spatial interpolation of geochemical data by multifractal IDW method}

The performance of inverse distance weighted multifractal interpolation is tested for the sparsely sampled regional geochemistry dataset by randomly removing samples from the dataset, interpolating the data at the remaining sample sites, and comparing the measured concentration at the removed sites with their respective interpolated values. Each dataset was performance tested five times by randomly removing $15 \%$ of the sample sites. For each of the datasets for each variable, more than half of the sample sites were removed and tested at least once in the performance evaluation. The test datasets are interpolated using the same methodology as the final interpolation grid maps, generating a set of plausible grid models of regional geochemistry that are used to calculate standard deviation estimates (interpolation uncertainty) for the entire dataset and by spatial location. The overall interpolation uncertainty for each variable is listed in Table 3 (Section 4.2.3) and the performance test results are portrayed as grids of interpolation 
uncertainty over the region. The interpolation uncertainty maps for multifractal IDW interpolation are provided in Section 6.0.

The overall performance (interpolation uncertainty) of the interpolation grids, expressed as the square root of the prediction variance, is positively correlated with the standard deviation of the measured variable in the sample dataset (Table 3 in Section 4.2.3). To test whether the variation of the residuals within individual data sets vary as a function of concentration (heteroscedastic variance), standardardized residual values for the performance test data were calculated for observations grouped by equal concentration intervals for individual data sets. The standardized residual value is calculated as the observed minus predicted group value divided by the square root of the residual mean square for the data set. Separate standardized residual values were calculated for positive and negative deviation from the estimated value for each concentration interval group. The results of this variance test are shown in plots of the standardardized residual value of the concentration interval versus the standardized estimated concentration for the group (Figures 1-3). Figures 1-3 group the data sets into major element, trace element, and trace metal categories; this allows data trends to be easily seen. All data shows similar ranges of standardized residual value and standardized estimated concentration. All data, with the exception of $\mathrm{Al}_{2} \mathrm{O}_{3}, \mathrm{SiO}_{2}$, and $\mathrm{Na}_{2} \mathrm{O}$ appear to be heteroscedastic where the absolute value of the standardized residual value increases with increasing concentration.

\section{major oxides: group standard residual value versus normalized concentration estimate}

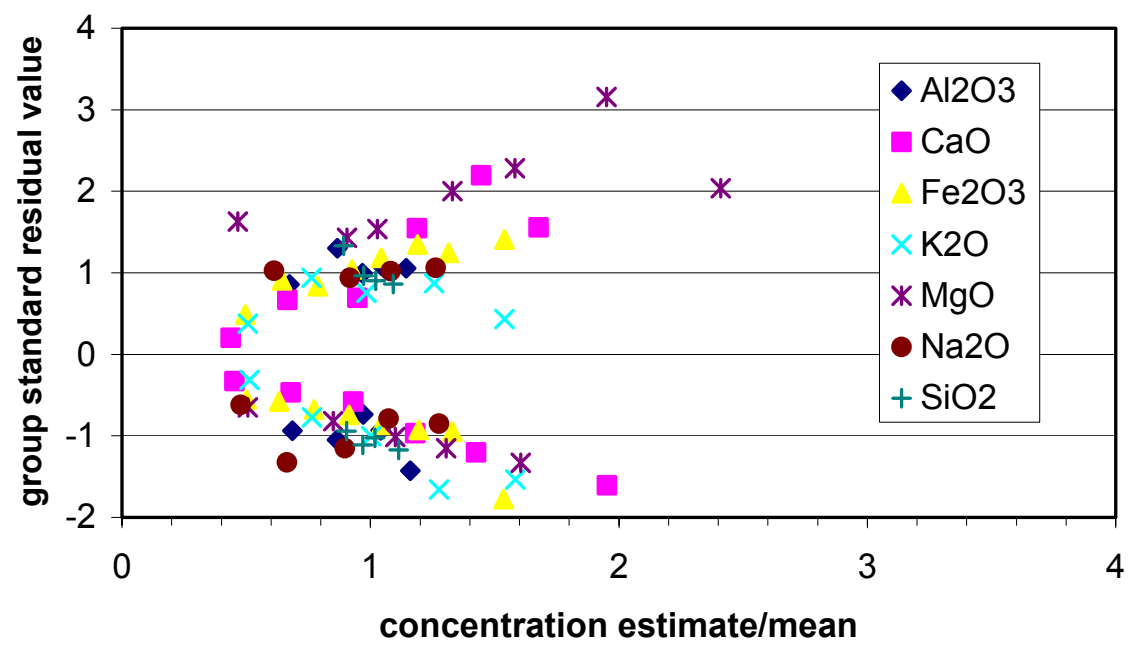


trace elements: group standard residual value versus normalized concentration estimate

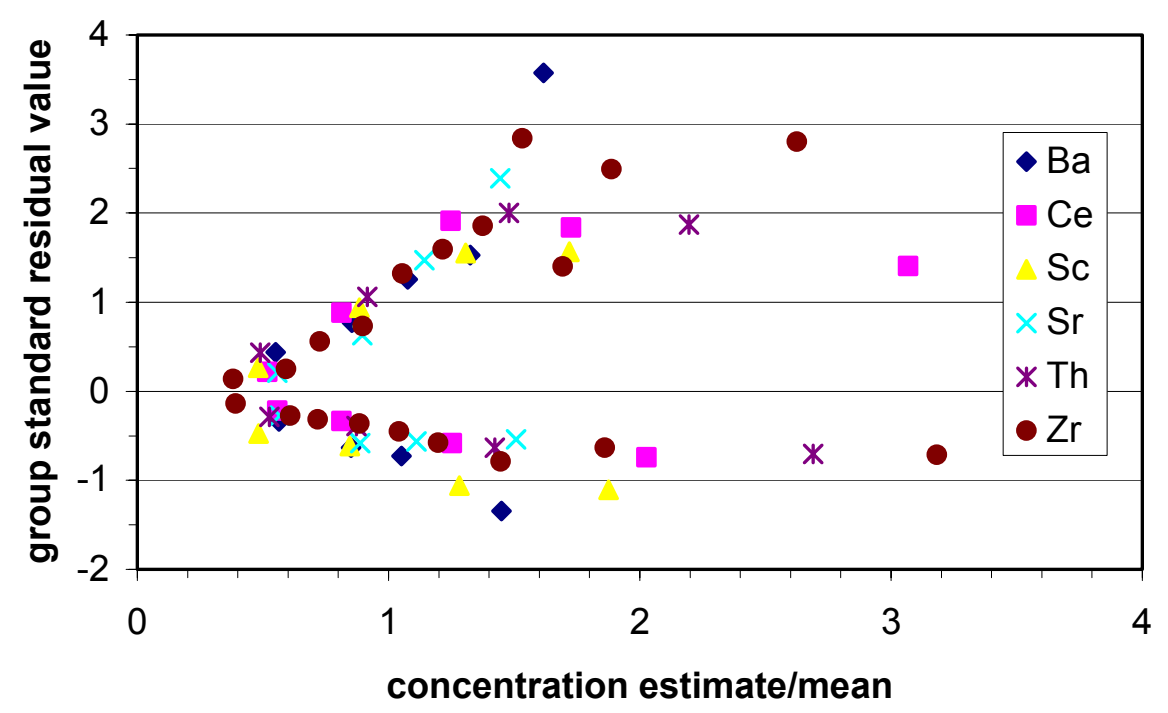

trace metals: group standard residual value versus normalized concentration estimate

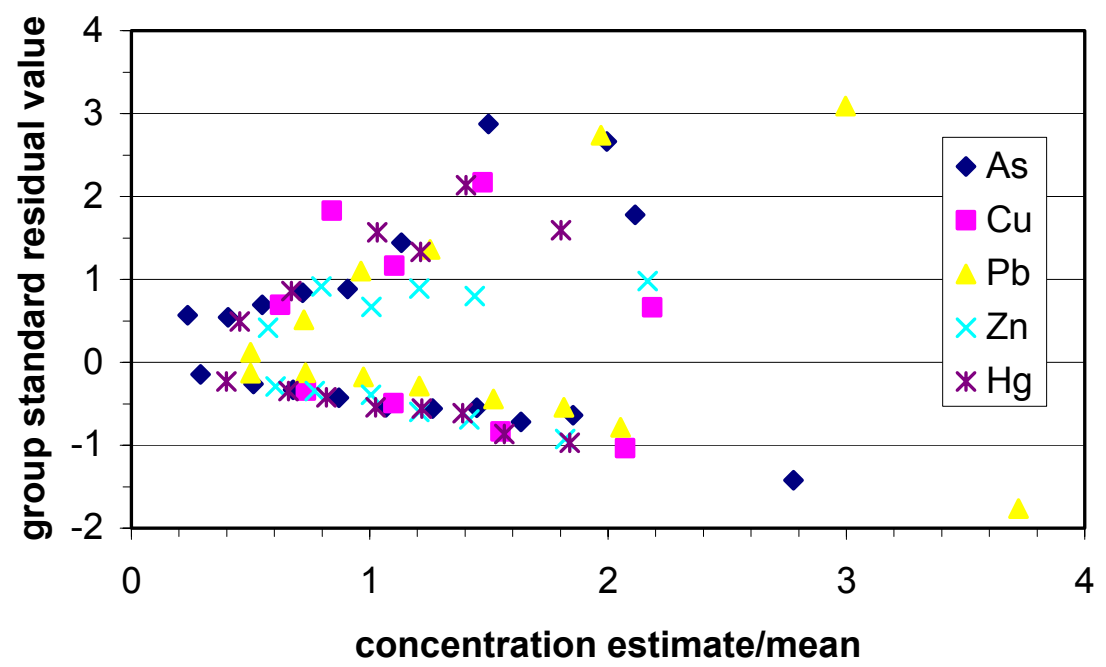




\subsubsection{Universal Kriging interpolation}

Universal kriging is used as an alternative interpolation method. This technique provides a more general representation of regional patterns in geochemistry as compared to IDW interpolation. Universal kriging is used for spatial prediction in settings where the data are expected follow a trend, varying in both mean (expected value) and variance by location (Johnston, et. al. 2001). The use of universal kriging in this geochemical study is supported by the geochemical variation in the stream sediment and water chemistry data categorized by bedrock lithology group across the study area (box plots by bedrock lithology in Section 6.0). The universal kriging technique applies a trend surface (i.e. a moving average value) to the study area using five local neighbors in the prediction of values at a spatial location (five is the default setting offered by ArcGIS 8 Geostatistical Analyst extension). In this respect, universal kriging is a more powerful technique than other kriging methods (such as ordinary kriging), as it accounts for data variation by this nonrandom trend surface (Johnston, et. al. 2001).

Universal kriging uses the spatial model:

$$
\hat{\mathrm{Z}}\left(s_{0}\right)=\sum_{j=1}^{N} f_{j}\left(s_{0}\right) \beta_{j}+\varepsilon\left(s_{0}\right)
$$

where again $\hat{Z}$ is the interpolated chemical value of the grid cell, $s_{0}$ is the spatial location of the prediction grid cell ( $x, y$ coordinates), $F \beta$ is the trend function, and $\varepsilon$ is a random error value assigned to the particular grid cell (Pebesma, 1998). The error values are used to fit a distance vs. direction model between measured points in a semivariogram. The trend function is added to this error model to produce the final grid interpolation (Johnston, et. al. 2001). The universal kriging interpolation maps are provided in Section 6.0 .

Kriging interpolation assumes the dataset has a stationary condition. Universal kriging allows for a weak stationary condition, where the mean and variance may vary regularly with location (Henley, 2001). The log values for stream sediment and water chemistry data were used in the interpolation to normalize the data in order to meet this condition, and converted back to the original values in the map legends. The legends for the universal kriging interpolation grid maps use the same value breaks as the multifractal IDW interpolation maps $\left(20 \mathrm{th}, 30 \mathrm{th}, 40 \mathrm{th}, 50 \mathrm{th}, 60 \mathrm{th}, 70 \mathrm{th}, 80_{\mathrm{th}}, 90_{\mathrm{th}}\right.$, and $95_{\mathrm{th}}$ percentile values), This allows for an easy comparison of results between the two grid interpolation methods.

\subsubsection{Uncertainty in spatial interpolation of geochemical data by kriging method}

The performance of the universal kriging interpolation method is calculated using the estimation variance generated during the model fit of the semivariogram, producing a standard error map. These grids were generated using the universal kriging standard error map function within the ArcGIS Geospatial Analyst extension. The logarithmic transform was used to calculate the standard error maps for the heteroscedastic data sets, as the 
absolute magnitude of the residual values increases with increasing estimated concentration (Figures 1-3). The interpolation uncertainty maps for universal kriging interpolation are provided in Section 6.0. The trend function formulated in universal kriging may be overestimated, which can lead to a degree of inaccuracy in uncertainty (Johnston, et. al. 2001), however the goal of this technique to provide a general regional pattern is maintained. The legends for the universal kriging interpolation grid maps use the same value breaks as the multifractal IDW interpolation maps, in order to easily compare the results.

\subsection{Geochemical Statistics}

\subsubsection{Box Plots}

Box plots of the chemical data, grouped by bedrock lithology group categories, show the $5^{\text {th }}, 25^{\text {th }}, 50^{\text {th }}, 75^{\text {th }}$, and $95^{\text {th }}$ percentiles for the chemical data for each lithology group.

\subsubsection{Geochemical Statistics, by bedrock lithology groups, drainage basin, and population density}

Median values are generally the best measure of central tendency in regional geochemical datasets (Reimann and Filzmoser, 2000). Median values of the chemical data were calculated for map polygon areas using the Point-Stat-Calc extension for ArcView v.3.2 (Dombroski, 2000). Stream sediment and water sample sites are grouped by polygons representing individual rock lithology groups and hydrologic basins in New England. Stream sediment data for base metals $(\mathrm{Cu}, \mathrm{Hg}, \mathrm{Pb}, \mathrm{Zn})$, which are commonly found in areas of human infrastructure, are also grouped by population density categories.

The legends for the median-value maps are based on the standard deviation of the range in median values of data for each of the polygons of grouped stream sediment sample sites. The cutoffs between the color-categories for each map are the standard deviation intervals $(-3,-2,-1,0,1,2,3)$ about the average of median values.

\subsubsection{Descriptive Statistics and QQ plots}

Descriptive statistics of the stream sediment and water chemistry data are provided in Table 3. Quantile-Quantile (QQ) plots of the stream sediment and water chemistry data are provided to display the distribution patterns of the data. QQ plots compare ordered values of a variable with quantiles of a theoretical distribution. Normal and lognormal theoretical distributions are used in the QQ plots in this report. If the data are normally (or lognormally) distributed with mean (u) and standard deviation (s), the data points on the QQ plot should lie approximately on a straight line with intercept $u$ and slope s. Curvature of the trend of points indicates departures from normality. The standard normal scores are calculated by taking the Z-score of the data ranked by ascending order. The Z-scores are the inverse values of the standard normal cumulative distribution, based on the probability $\mathrm{p}=$ rank value $-0.5 /$ rank value* total $\mathrm{N}$ samples. 
Table 3. Descriptive Statistics

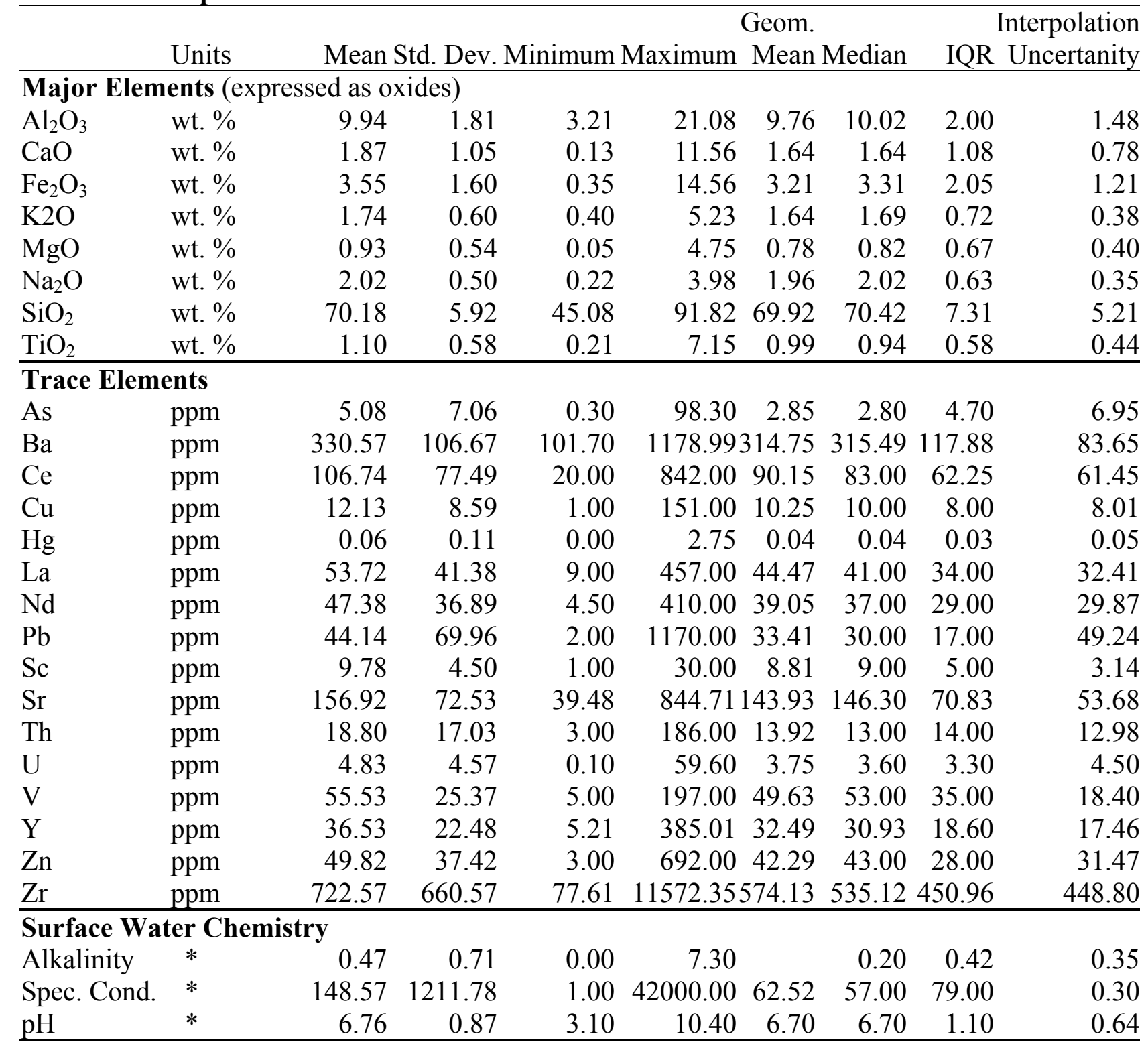

(* for unit measurement details see Surface Water Chemistry (3.2) in Section 3.0) 


\title{
5.0 Geochemical Groups and Associations
}

\author{
5.1 Stream Sediment Major elements \\ (expressed as oxides $\mathrm{Al}_{2} \mathrm{O}_{3}, \mathrm{CaO}, \mathrm{Fe}_{2} \mathrm{O}_{3}, \mathrm{~K}_{2} \mathrm{O}, \mathrm{MgO}, \mathrm{Na}_{2} \mathrm{O}$, $\mathrm{SiO}_{2}, \mathrm{TiO}_{2}$ ):
}

The depositional setting of stream sediments strongly influences the mineralogy of the sediments and their concentrations of major elements. High values of $\mathrm{SiO}_{2}$ are associated with areas of coarser silt and sand-rich sediments in areas of glacial outwash deposits and quartz-rich and feldspar-mica-poor source rocks. High $\mathrm{Al}_{2} \mathrm{O}_{3}$ is associated with areas of clay and silt-rich sediments in areas dominated by glacial till and aluminous rocks such as schist and phyllite. $\mathrm{SiO}_{2}$ and $\mathrm{Al}_{2} \mathrm{O}_{3}$ tend to show antithetic relationships to one another, reflecting the variation between quartz silt and clay in the sediment. $\mathrm{Na}_{2} \mathrm{O}$ and $\mathrm{K}_{2} \mathrm{O}$ are high over areas of granites, reflecting the influence of feldspar silt and detrital micas. $\mathrm{CaO}$ and $\mathrm{MgO}$ are high over areas of carbonate rocks (carbonate rock and calcpelite rock group categories), reflecting the influence of soluble carbonate and calcsilicate minerals. $\mathrm{Fe}_{2} \mathrm{O}_{3}$ and $\mathrm{TiO}_{2}$ are high in some areas of metamorphic rocks that weather to sediments containing magnetite and ilmenite in the silt-size heavy mineral suite.

\subsection{Stream Sediment Trace Elements:}

\subsubsection{Alkali Earths (Ba, Sr):}

Elevated concentrations generally occur in stream sediments associated with clastic metamorphic rocks and intermediate to mafic igneous rocks.

\subsubsection{First-Row Transition elements (Sc, V):}

Elevated concentrations of $\mathrm{Sc}$ and $\mathrm{V}$ occur in stream sediments associated with mafic rocks and carbonate-bearing metamorphic rocks. Chemical variation in $\mathrm{Sc}$ and $\mathrm{V}$ is similar to variation in $\mathrm{Fe}_{2} \mathrm{O}_{3}$.

\subsubsection{Heavy Mineral suite (REE, $Z r, T h, U, Y, C e / Y b(n)$ ):}

Elevated concentrations of REE (Ce, $\mathrm{La}, \mathrm{Nd}), \mathrm{Zr}$, Th, Y, and $\mathrm{U}$ occur in silt- and sand-rich stream sediments enriched in the heavy-mineral suite of monazite (light REE, Th, U), zircon (Zr, U, heavy REE), and related minerals, such as xenotime (heavy REE). Monazite and zircon are resistant to weathering and are concentrated in the silt-sized heavy mineral fraction of stream sediments. Contributing sources of monazite to stream sediments include high-metamorphic-grade clastic metasedimentary rocks and REE-rich granites. Xenotime and zircon is often abundant in the heavy mineral suite derived from weathered alkali granites. Chondrite-normalized $\mathrm{Ce} / \mathrm{Yb}$ ratios $(\mathrm{Ce} / \mathrm{Yb}(\mathrm{n}))$ shows high values over areas dominated by monazite in the heavy-mineral suite and low values over areas dominated by zircon and xenotime in the heavy mineral suite. Chondrite rare earth element normalizing factors are from Evensen and others, (1978).

\subsubsection{Base and toxic metals ( $\mathrm{Cu}, \mathrm{Zn}, \mathrm{Pb}, \mathrm{As}, \mathrm{Hg})$ :}

Arsenic and the base metals $\mathrm{Cu}, \mathrm{Pb}, \mathrm{Zn}$ tend to be associated with Fe_Mnhydroxoxide minerals in stream sediments. Natural sources of base metals to stream 
sediments include weathered sulfide minerals $(\mathrm{As}, \mathrm{Cu}, \mathrm{Pb}, \mathrm{Zn}$ ), oxide and silicate minerals $(\mathrm{Zn})$, and mafic rocks $(\mathrm{Cu})$. Anthropogenic sources of base metals $(\mathrm{Cu}, \mathrm{Pb}, \mathrm{Zn})$ are related to industrial sites and automobile traffic. Anthropogenic sources of As to stream sediments include the past agricultural use of arsenical pesticides. Elevated $\mathrm{Hg}$ concentrations in stream sediments tend to occur in urban areas and areas affected by acid deposition.

\subsection{Factor Analysis:}

Factor analyses for groups of major elements $\left(\mathrm{Al}_{2} \mathrm{O}_{3}, \mathrm{CaO}, \mathrm{Fe}_{2} \mathrm{O}_{3}, \mathrm{~K}_{2} \mathrm{O}, \mathrm{MgO}\right.$, $\mathrm{Na}_{2} \mathrm{O}$ ) and trace metals $\left(\mathrm{Fe}\right.$ [in $\left.\mathrm{Fe}_{2} \mathrm{O}_{3}\right], \mathrm{Cu}, \mathrm{Zn}, \mathrm{Pb}, \mathrm{As}$ ) were performed to detect possible relationships between elements in the data set. The presence of one particular element in sediment may be associated with the presence of another element, due to natural concurrence or a particular land use characteristic in the area (such as an industrial site). The associations found between elements using factor analysis provide a means for predicting the presence of a particular element in sediment based on another. Calculations were performed using the Factor Analysis function in Statview 5.0.1, and factor names were determined by the two or more elements within the factor with the highest orthogonal solutions, which have the main association(s). For major elements, three factors were calculated, termed " $\mathrm{Fe}_{2} \mathrm{O}_{3} / \mathrm{MgO} / \mathrm{CaO}$ ", " $\mathrm{K} 2 \mathrm{O} / \mathrm{Al}_{2} \mathrm{O}_{3}$ ", and " $\mathrm{Na}_{2} \mathrm{O} / \mathrm{CaO}$ ". Two metal factors were determined, termed " $\mathrm{Fe}_{2} \mathrm{O}_{3} / \mathrm{Cu} / \mathrm{Zn}$ " and " $\mathrm{As} / \mathrm{Pb}$ ".

(Section 6.0 next page) 


\subsection{Geochemical Dataset Figure Index}

(See Figures.pdffile for graphics)

\subsection{General Figures for New England Study Area}

NURE water samples

Stream sediment samples

Geologic provinces, sample counts by geologic province

Bedrock lithology, sample counts by bedrock lithology

Hydrologic basins, sample counts by basin

Population density

\subsection{NURE Water Chemistry Figures}

Water sample chemistry (general) in New England

Universal Kriging Interpolation and Uncertainty Maps

Mutifractal IDW Interpolation and Uncertainty Maps

Box-plots by geologic province

Water sample chemistry median-values by bedrock lithology

Box-plots by lithology

Water sample chemistry median-values by hydrologic basin

Water sample chemistry median-values by population density

Box-plots by population density

\subsection{Stream Sediment Chemistry Figures}

Stream Sediment Chemistry, Universal Kriging Interpolation

Universal Kriging Uncertainty

Stream Sediment Chemistry, Multifractal IDW Interpolation

Multifractal IDW Uncertainty

Quantile-Quantile Plots for all stream sediment chemistry data

Stream Sediment Chemistry by Geologic Province (Box-plots)

Stream Sediment Chemistry by Bedrock Lithology (Maps and box-plots)

Stream Sediment Chemistry, by Hydrologic Basin (Maps)

$\mathrm{Cu}, \mathrm{Hg}, \mathrm{Pb}, \mathrm{Zn}$ by Population Density (Maps and box-plots)

\subsection{Stream Sediment Factor Analysis:}

Factor analysis chemistry in New England

Box-plots by geologic province

Factor analysis chemistry median-values by bedrock lithology

Box-plots by lithology

Factor analysis chemistry median-values by hydrologic basin

Factor analysis chemistry median-values by population density

Box-plots by population density 


\subsection{References Cited}

Agterberg, F.P., 2001, Multifractal simulation of geochemical map patterns, in, Merriam, D.F. and Davis, J.C. (eds.), Geologic modeling and simulation: Computer Applications in the Earth Sciences: Plenum Press, New York, p. 31-39.

Cheng, Q., 2003, GeoData Analysis System (GeoDAS) for Mineral Exploration and Environmental Assessment, User's Guide (GeoDAS Phase III): York University, Toronto, Ontario, Canada.

Dombroski, M., 2000, ESRI Arc View Extension: Point Stat Calc: U.S. Geological Survey Open-File Report 00-302 [available online at URL http://pubs.usgs.gov/of/2000/ofr-00-302/].

Englund, E.J., Weber, D.D., and Leviant, N., 1992, The effects of sampling design parameters on block selection: Mathematical Geology, v. 24, no. 3, p. 329-343.

Evensen, N.M., P.J. Hamilton, and R.K. O’Nions, 1978, Rare earth element abundances in chondrite meteorites: Geochemica et Cosmochimica Acta, v. 42, no.8, p.1199-1212.

Grossman, J. N., 1998, National Geochemical Atlas: The Geochemical landscape of the Conterminous United States Derived from Stream Sediment and other Solid Sample Media Analyzed by the National Uranium Evaluation (NURE): U.S. Geological Survey Open-File Report 98-622. ver. 3.01.

Henley, Stephen, 2001, The importance of being stationary: Earth Science Computer Applications, v. 16, no. 12 p. 1-3.

Johnston, K., J.M. Ver Hoef, K. Krivoruchko, and N. Lucas, 2001, Using ArcGIS Geostatistical Analyst: ESRI ArcGIS Manual, p. 133-135, 150-152.

MacDonald, D.D., 2000, Development and Evaluation of Consensus-Based Sediment Quality Guidlelines for Freshwater Ecosystems: Archives in Environmental Toxicology v. 39, p. 20-31.

McHone, J.G. and J. R. Butler, 1984, Mesozoic igneous provinces of New England and the opening of the north Atlantic ocean: Geological Society of America Bulletin, v. 95, p.754-765.

Pebesma, E. J., 1998, Gstat User's Manual (Section on Linear Models in Gstat): Department of Geography, Utrecht University, the Netherlands.

Reimann, C. and P. Filzmoser, 2000, Normal and lognormal data distribution in geochemistry: death of a myth. Consequences for the statistical treatment of geochemical and environmental data: Environmental Geology, v. 39, no.9, p. 1001-1014. 
Robinson, G. R., Jr. and K. E. Kapo, 2003, Generalized Lithology and Lithogeochemical Character of Near-Surface Bedrock in the New England Region: U.S. Geological Survey Open-File Report 03-225. U.S. Geological Survey, Reston, VA [available online at URL http://pubs.usgs.gov/of/2003/of03-225/].

Smith, S. M., 2001a, A manual for interpreting new-format NURE HSSR data files: U.S. Geological Survey Open-File Report 97-492, ver. 1.3 [available online at URL http://greenwood.cr.usgs.gov/pub/open-file-reports/ofr-97-0492/nure_man.htm].

Smith, S. M., 2001b, National Geochemical Database (Reformatted data from the National Uranium Resource Evaluation Hydrogeochemical and Stream Sediment Reconnaisance Program): U.S. Geological Survey Open-File Report 97-492, ver. 1.3. [available online at URL http:/pubs.usgs.gov/of/1997/ofr-97-0492/].

Steeves, P., and D. Nebert. 1994. Hydrologic units maps of the Conterminous United States: U.S. Geological Survey Open-File data set "huc250k", ed. 1. U.S. Geological Survey, Reston, VA. [available online at URL http://water.usgs.gov/lookup/getspatial?huc250k].

Taggart, J.E., 2002, Analytical methods for chemical analysis of geologic and other materials: U.S. Geological Survey Open-File Report 02-02230. ver. 5.0 [available online at URL http://pubs.usgs.gov/of/2002/ofr-02-0223/].

U.S. Census Bureau, U.S. Department of Commerce. 2000, Statistical Abstract of the United States: 2000, 120th edition: United States Department of Commerce. U.S. Census Bureau, Washington D.C. [Available online at URL http://www.census.gov/prod/www/abs/gen-ref.html].

U.S. Geological Survey, 2004, The National Geochemical Survey Database and Documentation: U.S. Geological Survey Open-File Report 04-1001 ver. 1.0. [entire database and documentation available online at URL http://tin.er.usgs.gov/geochem/doc/home.htm, and the New England dataset can be retrieved at http://tin.er.usgs.gov/geochem/doc/datasets/nure-2000ne.xls ].

Weber, D.D., and Englund, E.J., 1992, Evaluation and comparison of spatial interpolators: Mathematical Geology, v. 24, no. 4, p. 381-391.

Weber, D.D., and Englund, E.J., 1994, Evaluation and comparison of spatial interpolators, II: Mathematical Geology, v. 26, no. 5, p. 589-603.] 